\title{
Sustainable social development of municipalities located in national park and their environmental protection
}

\author{
Agata Pawłat-Zawrzykraj, Konrad Podawca \\ Warsaw University of Life Science, Faculty of Engineering and Environmental Science \\ Department of Civil Engineering, Nowoursynowska 159, 02-787 Warszawa \\ e-mail: agata_pawlat_zawrzykraj@sggw.pl
}

\begin{abstract}
Development of social infrastructure of rural areas and conservation of environmental valuable areas are one of the main objectives of local and national authorities. The main research problem presented in the article is to analyze the spatial accessibility of social infrastructure (understood as a 1st level service, such as: in case of education - kindergarten, primary and junior high schools, in case of health-care - health centers and clinics; in case of security - fire department and police) by local residents of the Izabelin Municipality located within the boundaries of the Kampinoski National Park.
\end{abstract}

Key words: national park, social infrastructure, service, spatial management.

\section{Introduction}

Multifunctionality combined with multi-conflictuality occurring in the areas of municipalities located in national parks pose to science specific cognitive, practical and methodological questions and topics (Stola 1987).

Issues raised in the article are complex. So far, studies focused on the characteristics of rural areas or protected land development issues. Nowadays one can observe placing an emphasis on nature protection and enlargement of protected areas on one hand, and anthropopressure on environmentally attractive areas on the other. Presence of a national park in the administrative boundaries of a municipality seems to be treated as a priority, whereas it seems that it should not be put before meeting basic needs of the population.

Many people wonder if harmonious coexistence of a park and a local, mainly municipal authorities, which represents inhabitants of the park and its' protection zone is possible. Many researchers conclude that in the present state, the answer to that question is negative (Sowa 2002). One should remember that those are functioning structures and the coexistence of natural and social spheres is a reality which has to rely on broadly comprehended balance of sustainable development. Therefore, scientific study of functional and social diversity of municipalities located in national parks should be the starting point for plotting the correct directions of the transition from existing to a desired state.

The issue presented above was analyzed on the example of the Izabelin Municipality, located within the boundaries of the Kampinoski National Park. The Municipality has already quite broadly developed settlement network. Environmental attractiveness of the municipality as well as its' location in the neighborhood of the Warsaw agglomeration contributes to the further development of the residential areas and related services.

The main goal of the article is to make an analysis of the spatial accessibility of social infrastructure in the Izabelin Municipality taking into consideration optimal and 
maximal distance to the service, stated in literature, as well as Polish low regulations.

\section{Spatial management of municipalities located within or in the neighborhood of national parks}

The problem of spatial management of areas located within national parks or in their protection zones starts already at the administrative "path". The planning procedure for this kind of areas is usually elongated and in some cases even impossible to carry out. This is due to specific spatial management regulations concerning protected areas contrary to the existing reality, the dependence between and the validity period of the particular planning studies, as well as various interests of municipal and park authorities.

Problem of the development of such municipalities should not be only considered as a matter of legal regulations. A very important reason to deal with the subject, perhaps even more important than the legal aspect, is the social side of life and everyday existence on this kind of areas, related to the quality and availability of social infrastructure.

Barriers that appear regarding an access to basic educational and heath care facilities are the result of simultaneous impact of various factors, such as: difficult economical situation of and inadequate quantity of medical equipment in public health service, the introduction of education reform in 1999, economical problems concerning new investments, low health and educational awareness of the rural population (Kulikowski 2002; Michalski 2002; Rydz 2002).

The results of analyses regarding teaching level show lower educational standards in rural areas, lower educational degree of teachers and in terms of spatial aspects, more difficult transport of children to schools which is linked to liquidation of approximately five thousand educational institutions, which elongated the distance from home to school by $50-100 \%$ (Kulikowski 2002).

It is estimated that, e.g. the average radius of area determined by school service for a secondary school is equal to $5.5 \mathrm{~km}$ (Rydz 2002). Whereas, according to Article 17 of the Act on Educational System (Dz. U. $1991 \mathrm{Nr} 95$ poz. 425), it should not exceed $4 \mathrm{~km}$. There is talk of reducing the differences between city and country. Unfortunately, those differences are still large in terms of providing for basic and higher level needs. That said, there is a question: what is the situation in municipalities located within or in a neighborhood of national parks and whether the location in the park has some significance in comparison to the average situation in the country?

The problem concerns more than $4.5 \%$ of administration units in Poland (114 administration units out of 2,478 municipalities and 886 cities - including 579 located in urban-rural municipalities).

\section{Availability of social infrastructure}

Social infrastructure is a basic group of services consisting of the system objects and institutions providing decent living conditions in the living environment (Chmielewski 2001).

In terms of meeting the basic human needs, the most important one is to have good access to health services, education and a sense of security. According to classification of services proposed by Chmielewski (2001), such services are performed by social infrastructure, included in the public infrastructure. In the context of spatial management, the access is estimated as a distance between an object and the place of residence and is associated with the implementation of endogenous functions of the municipality.

Location of services depends on the type and nature of the administrative unit as well as the population density. In general, in rural areas, the service radius from the basic service facilities should not exceed $3 \mathrm{~km}$, while in a city - the maximum of $1 \mathrm{~km}$ which is a walking distance (Wieczorkiewicz 1995). The optimal distances are smaller and are presented in the work by Chmielewski (2001). According to this author, the optimal distance to health-care services (i.e. a health clinic and a pharmacy) in urban areas is $500 \mathrm{~m}$. In the case of primary and junior high schools, the maximal distance is $600 \mathrm{~m}$ and the optimal distance $500 \mathrm{~m}$. For kindergartens those distances are 350 and 250 $\mathrm{m}$, respectively (Fig. 1).

In some cases, service availability is determined by law. The School Education Act (Dz. U. 1991 Nr 95 poz. 425) determines the rules in the case of kindergartens, primary and secondary schools. It states that:

a) The child's route from home to school can not exceed $3 \mathrm{~km}$ in the case of pupils in grades I through IV of primary schools $-4 \mathrm{~km}$ for pupils of grades $\mathrm{V}$ and VI of primary and junior high school;

b) In case of a six-year-old, route from home to the nearest public kindergarten or preschool division in elementary school should not exceed $3 \mathrm{~km}$.

\section{The study area}

The Izabelin Municipality was established on 1st of January 1995 by dividing of Stare Babice Municipality. It currently consists of seven rural districts located to the northwest of Warsaw, surrounded by the Kampinoski National Park (Fig. 2). In terms of administrative location, it belongs to one of seven municipalities of the Warsaw-West County, which is a part of Masovia Voivodship. Due to it's location 


\begin{tabular}{|c|c|c|c|c|c|c|c|c|}
\hline \multirow[b]{2}{*}{$\begin{array}{c}\text { DISTANCE TO } \\
\text { RESIDENCE } \\
\text { AREA } \\
{[\mathrm{m}]}\end{array}$} & \multicolumn{8}{|c|}{ TYPE OF SERVICE } \\
\hline & 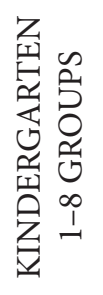 & 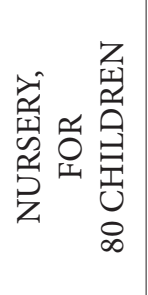 & 密号 & 空 & 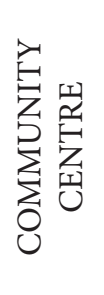 & 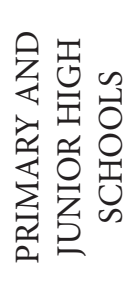 & 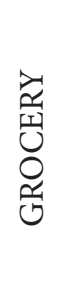 & 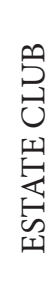 \\
\hline 50 & & & & & & & & \\
\hline 100 & & & & & & & & \\
\hline 150 & & & & & & & & \\
\hline 200 & & & & & & & & \\
\hline 250 & & & & & & & & \\
\hline 300 & & & & & & & & \\
\hline 350 & & & & & & & & \\
\hline 400 & & & & & & & & \\
\hline 450 & & & & & & & & \\
\hline 500 & & & & & & & & \\
\hline 550 & & & & & & & & \\
\hline 600 & & & & & & & & \\
\hline 650 & & & & & & & & \\
\hline 700 & & & & & & & & \\
\hline 750 & & & & & & & & \\
\hline 800 & & & & & & & & \\
\hline 850 & & & & & & & & \\
\hline 900 & & & & & & & & \\
\hline 950 & & & & & & & & \\
\hline 1000 & & & & & & & & \\
\hline & \multicolumn{8}{|c|}{ Optimal distance to the service } \\
\hline & \multicolumn{8}{|c|}{ Maximum distance to the service } \\
\hline
\end{tabular}

Figure 1. Basic services location in urban areas. Prepared on the basis of Chmielewski (2001)

and functional connection with Warsaw the Municipality is assigned to Warsaw Agglomeration.

Izabelin, from which comes the name of the Municipality, is the youngest village in the whole Municipality and in the beginning (the beginning of the twentieth century) it was a minor summer resort for professional army officers and craftsmen. The increased settlement development has been observed in the area since 1918 .

Dynamic urban development of the current Izabelin Municipality took place in the interwar period (intensive process of land allotment) and in the last quarter century. Significant increase in community development dynamics has been observed since it gained its autonomy, i.e. after 1995.

The main reason of choosing the Izabelin Municipality as a study area is the fact that as much as $86 \%$ of the Municipality is located within the Kampinoski National Park, whereas the remaining $14 \%$ is located in its protection zone. Furthermore, over $75 \%$ of the area is covered by forest. 


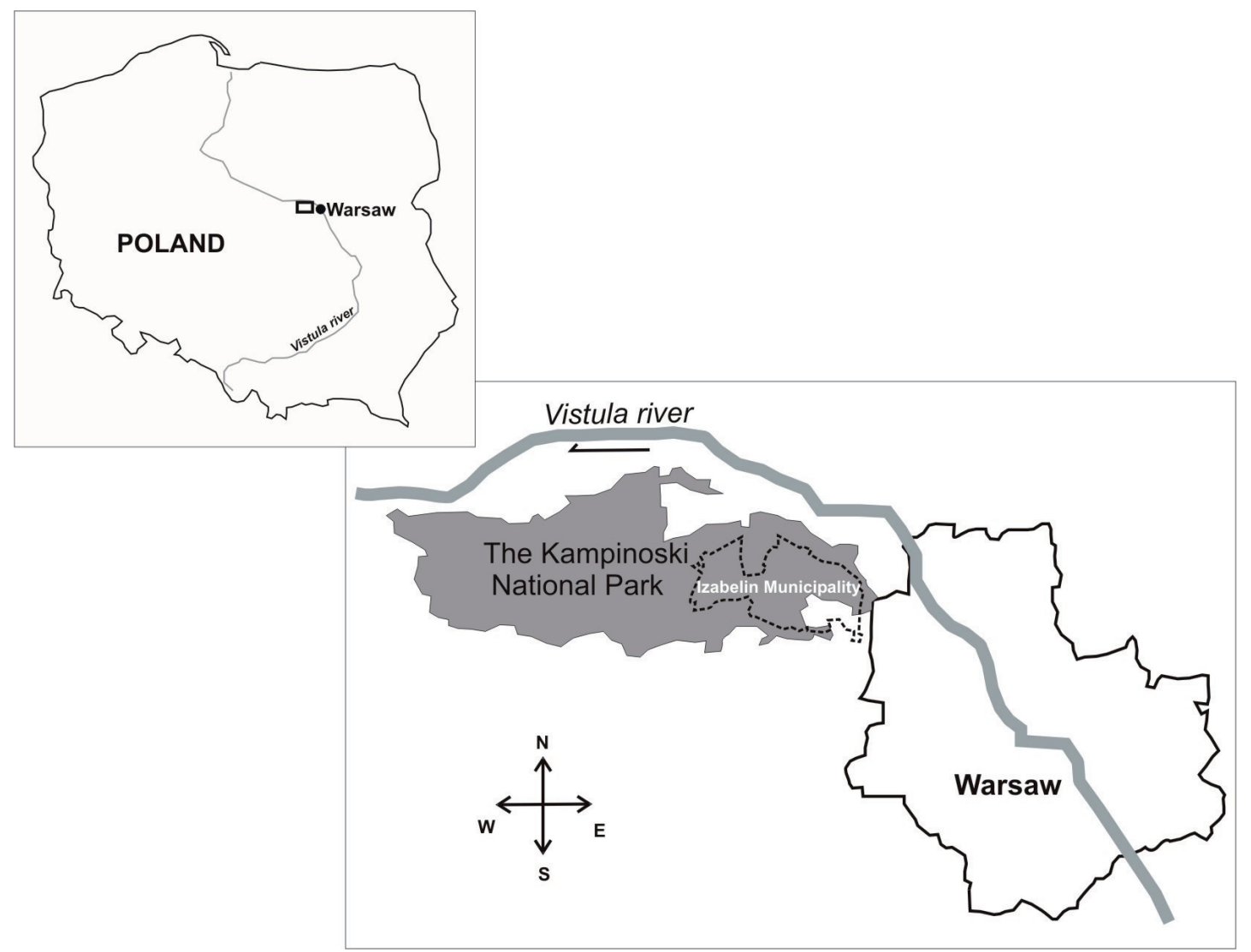

Figure 2. Location of the study area

\subsection{Environmental conditions}

The Izabelin Municipality, according to the National Ecological Network ECONET-Poland (Liro 1995), is located in a core area of international importance (20M) associated with The Kampinoski Primeval Forest where the protected area of The Kampinoski National Park was established. The Park includes the well preserved complex of forests typical for valleys of central Poland. The characteristic features of this area are coniferous forests on high sandy terraces with dunes as well as marsh meadows located in so-called deflation basins (Podawca et al. 2005).

Since the 1st of May 2004, time of Polish accession to the European Union, a priority task of national ecological policy was to introduce European Ecological Network NATURA 2000, according to adopted Directives:

- Birds Directive on the conservation of the wild birds (79/409/EEC), requiring the protection of all wild bird species naturally occurring in the European territory of the Member States. It sets rules for the protection, management and control of the species and regulating the birds acceptable usage. The Directive obligates to protect habitats of all the species by creation of Special Protection Areas (SPA),

- Habitats Directive on the conservation of natural habitats and of wild fauna and flora (92/43/EEC). The Directive obligates to indicate Special Area of Conservation (SAC) - for natural habitat types, species of fauna and flora - and strict protection system for animal and plant species. The species which may be subject to economic exploitation are also indicated.

European Ecological Network NATURA 2000 in the Izabelin Municipality refers to areas located within boundaries of the Kampinoski National Park.

In the Izabelin Municipality, within the Kampinoski National Park, there are several areas of strict protection, with no direct human interference in ecosystems, elements of nature or the course of natural processes, and in case of species - there is a year-round protection of specimen in all stages of their development:

- The Area of the Strict Protection Sieraków, established in 1937, covering the area of 1204.91 ha (partly within the administrative borders of the Izabelin Municipality). It is one of the largest and the most environmentally 
valuable areas in Poland with parabolic dunes, marshy basin and swamps.

- The Area of the Strict Protection Cyganka - est. in 1977, covering the area of 99.34 ha. Part of marshy basin Niepust and dunes Bór Niepustowy with a mosaic complex of primeval forest.

- The Area of the Strict Protection Zaborów Leśny - est. in 1959, covering the area of 90.60 ha. Includes dunes and swampy areas.

- The Area of the Strict Protection Kalisko - est. in 1977, covering the area of 119.45 ha. Part of a larger basin located on southern dell of swamps.

\subsection{The social structure of the residential units}

The historical population data on the Izabelin Municipality show a systematic increase in 1995-2004 (from 7,322 in 1995 to 9,905 in 2004) and a stabilization in the years 2005-2010 at the level of 9,992-10,500. However, the forecasts assume a dynamic urban population growth to 13,000 in 2015 and to 17,000 in 2020 (Bank danych regionalnych, GUS [Regional Data Bank, Central Statistical Office], 1995-2008; Cembrzyńska-Niebudek \& Makarewicz 2004) (Fig. 3). Therefore, it must be assumed that the existing social infrastructure in its current state will not meet the future needs of the community.

When examining an issue of population growth on the background of the particular settlement units one should note that it is fairly evenly distributed regardless of the spatial location of the village. For example the population of Izabelin C settlement increases from ca. 2,000 in 1996 to 4,000 in 2020 , whereas the population of the Truskaw settlement from ca. 1,500 in 1996 to 3,000 in 2020 (www. izabelin.pl; Cembrzyńska-Niebudek \& Makarewicz 2004) (Fig. 4). Therefore, the location of social infrastructure will be important not only for residents of the village commune.

\subsection{Social infrastructure in the Izabelin Municipality}

In the analyzed period in the Municipality Izabelin, there were:

- two public kindergartens (which in 1995 in seven groups there were 187 children, in 2004 in eight groups - 215 children and in 2006 in nine groups - 256 children): in Laski and in Izabelin C;

- col. S. Królicki Primary School in Izabelin with 24 groups, in which 554 pupils were studying in 2004 and 482 in 2008; the school served villages, such as: Izabelin C, Izabelin B, Truskaw, Hornówek and Sieraków; the second region included the villages Laski and Mościska was served by Primary School No. 79, located in Warsaw;

- secondary school located in Izabelin C with 12 groups, attended by 290 pupils in 2004 and 271 in 2008 .

Basic health services were met by: Communal Health Centre in Izabelin, SPZOZ Health Center (Independent Private Healthcare Center), Non-public Hospital - Clinic of Obstetrics and Female Diseases in Izabelin, Medical Rehabilitation Department for the Blind in Laski, approximately 10 private medical offices (not included in the analysis), Communal social welfare center.

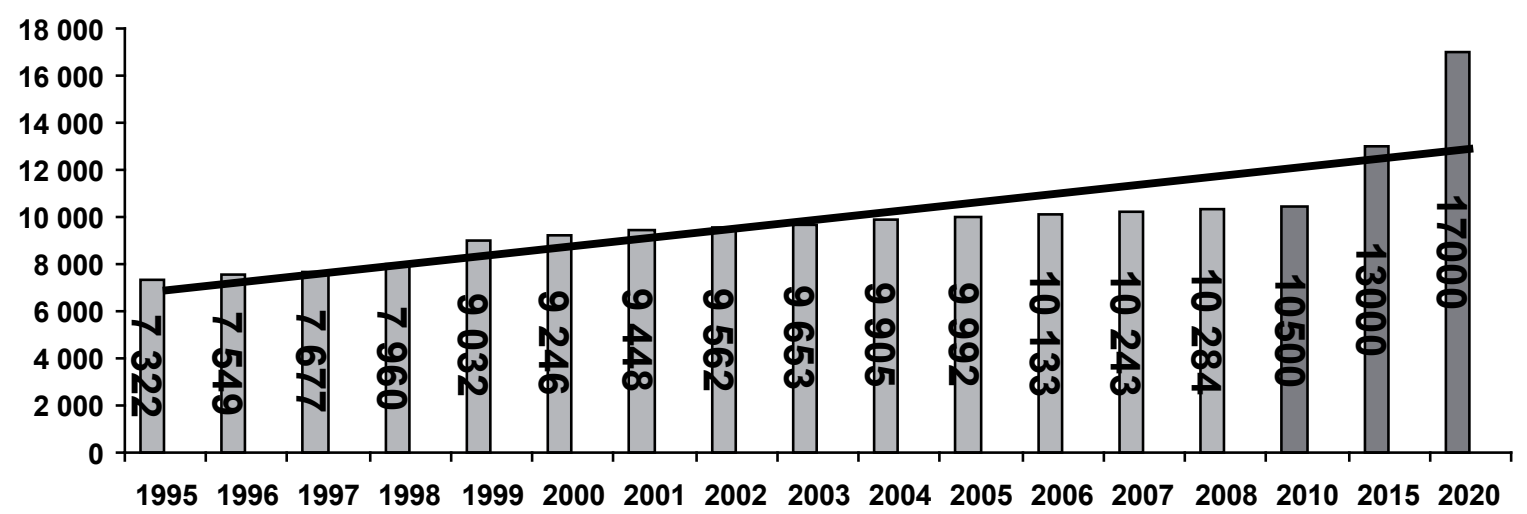

$\square$ overall population $\square$ prognosis population $\longleftarrow$ linear trend in population

Figure 3. Population of the Izabelin Municipality between 1995-2008 (Bank danych regionalnych 1995-2008, GUS [Regional Data Bank 1995-2008, Central Statistical Office], and forecasts for the period of 2010-2020 (CembrzyńskaNiebudek \& Makarewicz 2004) 


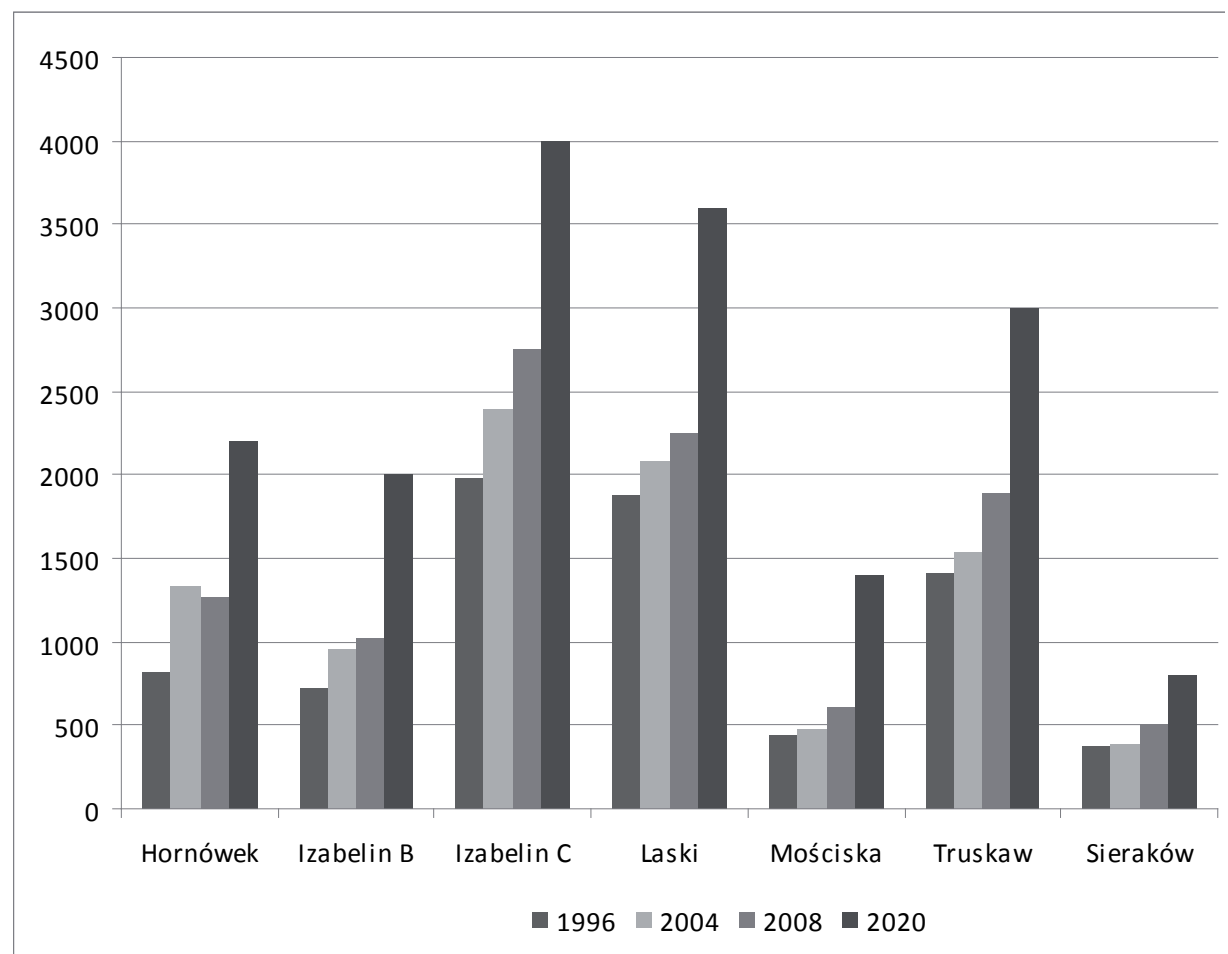

Figure 4. The Population against the settlement network of the Izabelin Municipality (www. izabelin.pl; Cembrzyńska-Niebudek \& Makarewicz 2004)

In terms of public security the key factor is the distance from the villages to particular police and fire stations, which are: District Police Office in Izabelin; Voluntary Fire Brigade in Laski, Voluntary Fire Brigade in Izabelin; Firefighter Service of the Kampinoski National Park.

\section{Methods}

Data on the location of the existing service facilities in the Izabelin Municipality came mainly from the municipal authorities. The service radius for a particular kind of the 1 st level service was drawn on maps of the Municipality. The size of the service radius is related to the optimal distance between an object and the place of residence, which was discussed in the literature presented above. The approximate percentage of the serviced villages was calculated using the MapInfo Software.

\section{Results - accessibility of the 1st level services in the Izabelin Municipality}

The easiest method to illustrate the accessibility of the $1 \mathrm{st}$ (the lowest) level service is to provide an approximate per- centage of settlement unit area serviced by certain type of service located in the walking distance and to measure service radius of a municipal unit. Maps presented below show the area of the municipality serviced by the educational (Fig. 5), health (Fig. 6) and security service (Fig. 7).

Approximate percentage of the serviced villages, presented in the Table 1, show large spatial diversification. The optimal service radius from the education and health facilities is within the distance of $0,5 \mathrm{~km}$, maximum $3 \mathrm{~km}$. In terms of education, only two villages (Izabelin C and Laski) can be partly serviced within the optimal distance; whereas the maximum service radius cover almost all villages. In case of health service - only three villages (Hornówek $-15 \%$ of the area, Izabelin $\mathrm{C}-25 \%$ of the area and Laski $-30 \%$ ) can be partly serviced within optimal distance, but almost all villages (except for Truskaw) are located within the maximum service radius. The service radius for the security facilities can be larger: $1 \mathrm{~km}-$ the optimal distance and $4 \mathrm{~km}$ - the maximum distance. In this case, large area of three main villages (Izabelin C, Hornówek, Laski) are located in optimal distance from the service objects, and all villages are located in maximum distance from the objects.

Looking at the current spatial structure of the municipality, one can observe that the main villages are close- 


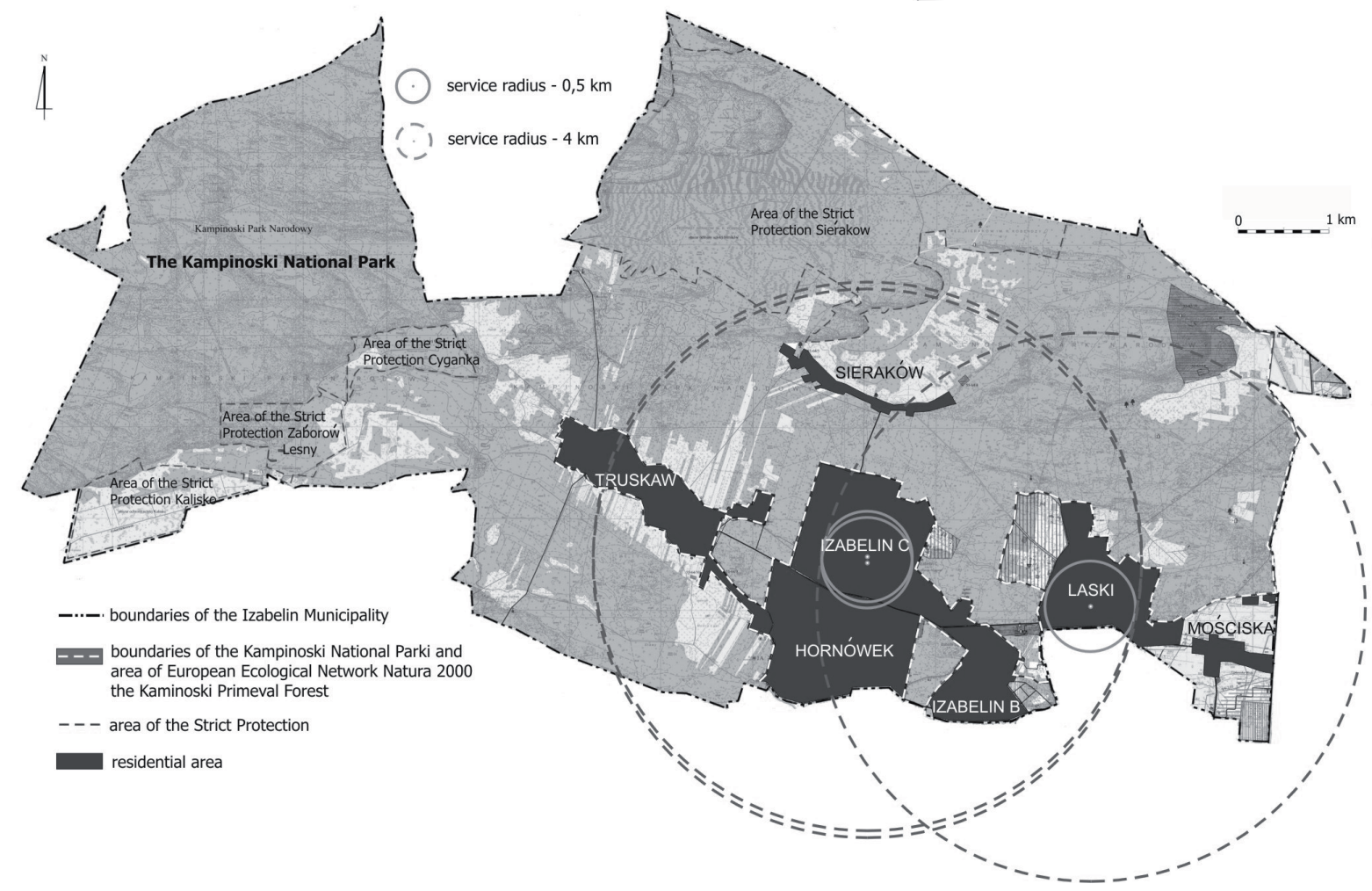

Figure 5. Area of the Municipality serviced by the educational service

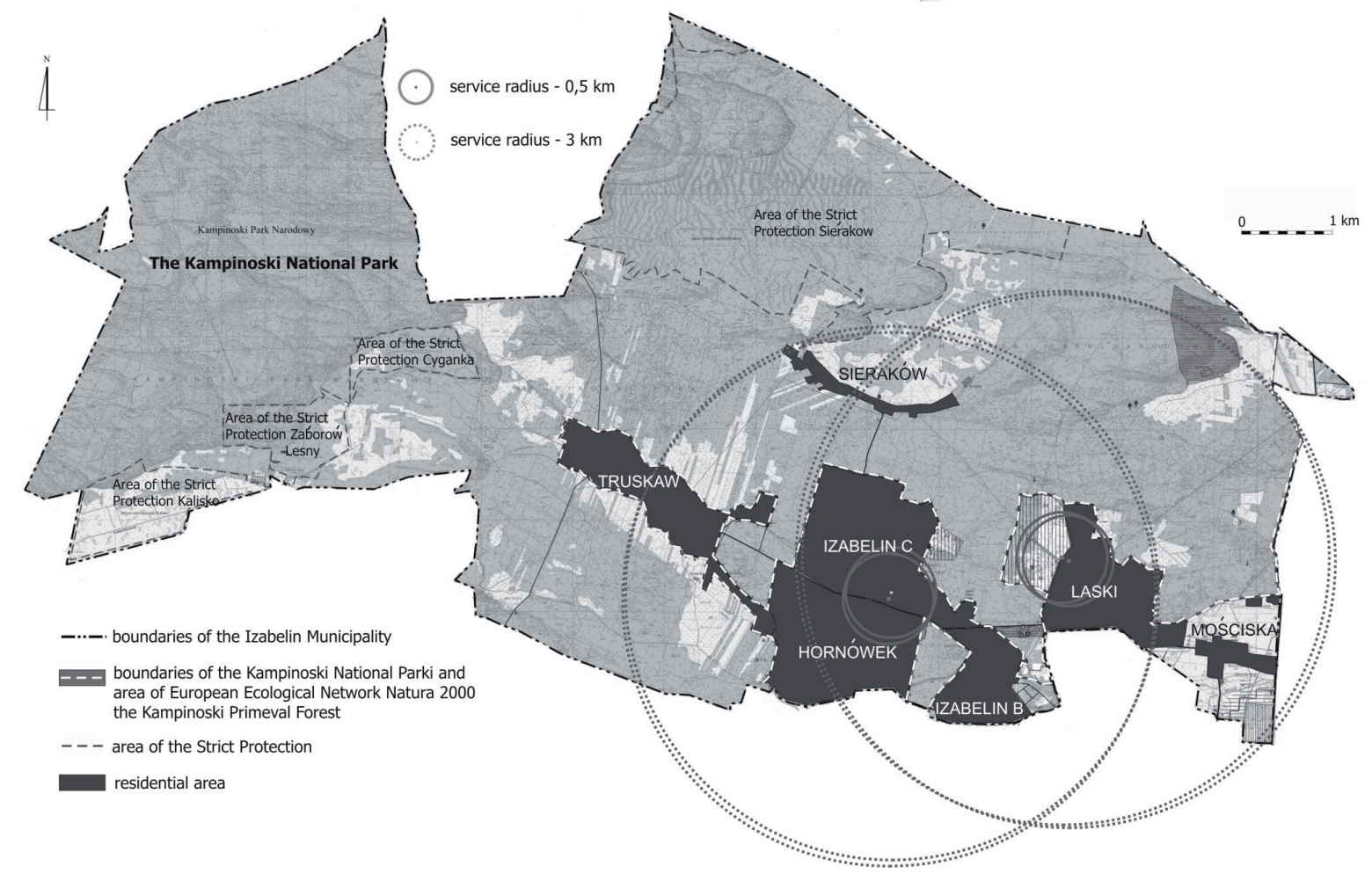

Figure 6 . Area of the Municipality serviced by the health service 


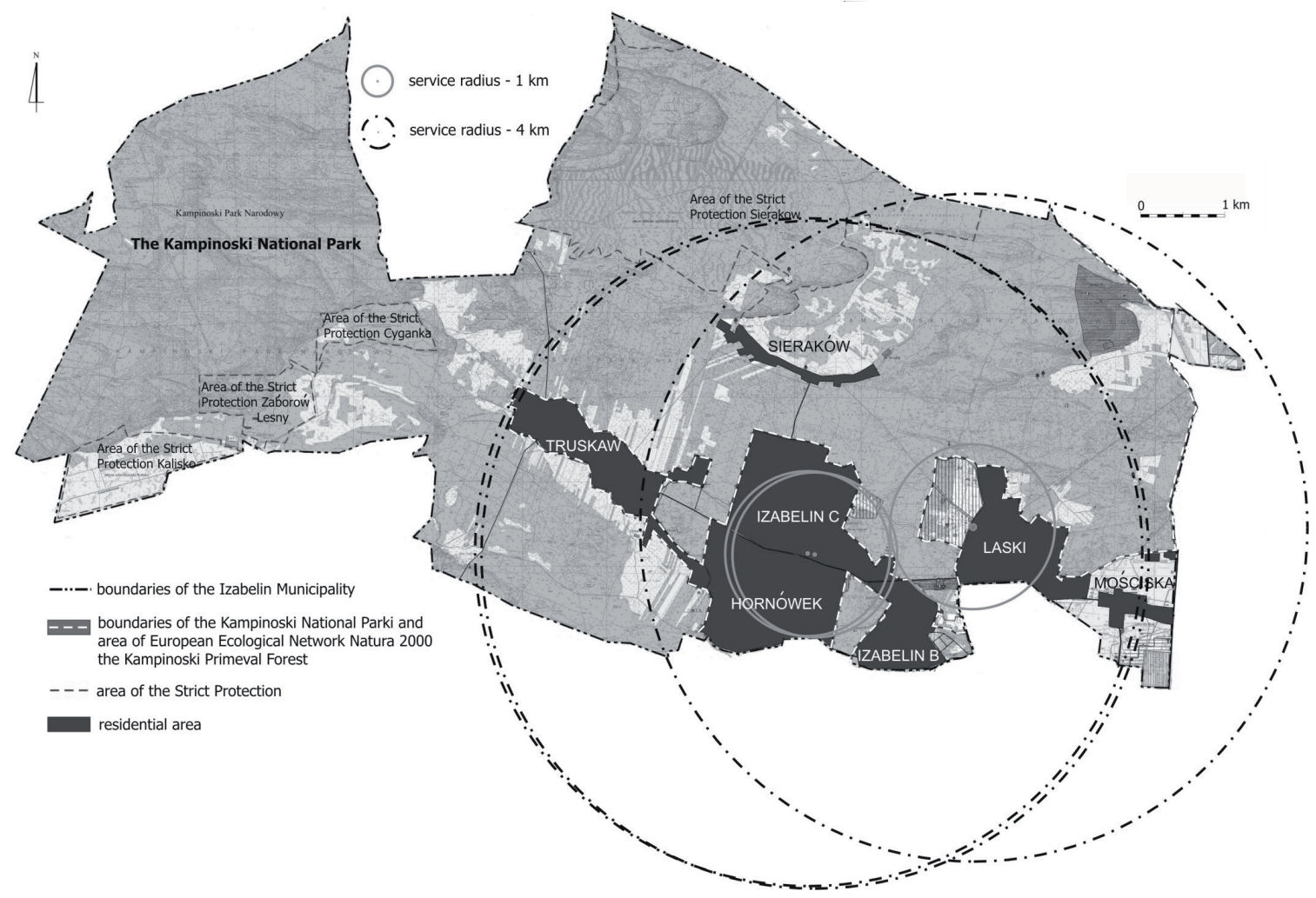

Figure 7. Area of the Municipality serviced by the public security service

Table 1. Accessibility of the 1st level services in the Izabelin Municipality

\begin{tabular}{|c|c|c|c|c|c|c|c|c|c|}
\hline \multirow{3}{*}{ SERVICE } & \multirow{3}{*}{ OBJECT } & \multirow{3}{*}{ 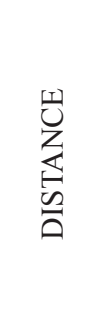 } & \multicolumn{7}{|c|}{ VILLAGES } \\
\hline & & & 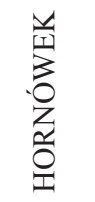 & 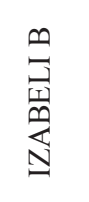 & 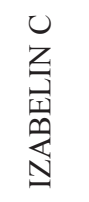 & 尝 & 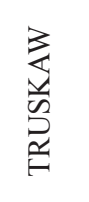 & 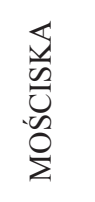 & 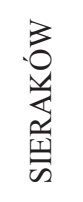 \\
\hline & & & APPI & XIMAT & PERCE & ГAGE C & SERVI & D VILL & GES \\
\hline \multirow{6}{*}{ 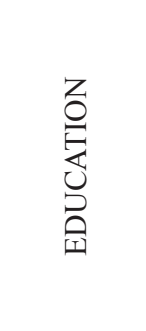 } & \multirow{2}{*}{ KINDERGARDEN } & $0.5 \mathrm{~km}$ & $5 \%$ & $0 \%$ & $50 \%$ & $60 \%$ & $0 \%$ & $0 \%$ & $0 \%$ \\
\hline & & $3 \mathrm{~km}$ & $100 \%$ & $100 \%$ & $100 \%$ & $100 \%$ & $70 \%$ & $100 \%$ & $100 \%$ \\
\hline & \multirow{2}{*}{ PRIMARY SCHOOL } & $0.5 \mathrm{~km}$ & $5 \%$ & $0 \%$ & $50 \%$ & $0 \%$ & $0 \%$ & $0 \%$ & $0 \%$ \\
\hline & & $3 \mathrm{~km}$ & $100 \%$ & $100 \%$ & $100 \%$ & $85 \%$ & $70 \%$ & $0 \%$ & $100 \%$ \\
\hline & \multirow{2}{*}{$\begin{array}{l}\text { JUNIOR HIGH } \\
\text { SCHOOL }\end{array}$} & $0.5 \mathrm{~km}$ & $5 \%$ & $0 \%$ & $50 \%$ & $0 \%$ & $0 \%$ & $0 \%$ & $0 \%$ \\
\hline & & $3 \mathrm{~km}$ & $100 \%$ & $100 \%$ & $100 \%$ & $85 \%$ & $70 \%$ & $0 \%$ & $100 \%$ \\
\hline \multirow{2}{*}{ 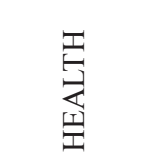 } & \multirow[b]{2}{*}{$\begin{array}{l}\text { HEALTH CLINIC, } \\
\text { HEALTH CENTER }\end{array}$} & $0.5 \mathrm{~km}$ & $15 \%$ & $0 \%$ & $25 \%$ & $30 \%$ & $0 \%$ & $0 \%$ & $0 \%$ \\
\hline & & $3 \mathrm{~km}$ & $100 \%$ & $100 \%$ & $100 \%$ & $100 \%$ & $50 \%$ & $100 \%$ & $100 \%$ \\
\hline \multirow{2}{*}{ 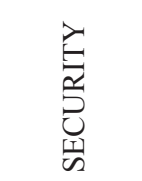 } & \multirow[b]{2}{*}{$\begin{array}{l}\text { FIRE DEPARTAMENT } \\
\text { POLICE }\end{array}$} & $1 \mathrm{~km}$ & $70 \%$ & $0 \%$ & $80 \%$ & $80 \%$ & $0 \%$ & $0 \%$ & $0 \%$ \\
\hline & & $4 \mathrm{~km}$ & $100 \%$ & $100 \%$ & $100 \%$ & $100 \%$ & $100 \%$ & $100 \%$ & $100 \%$ \\
\hline
\end{tabular}


ly surrounded by the Kampinoski National Park, which strongly limits the spatial development of the units. Further settlement development of Izabelin C, Izabelin B, Hornówek, Laski, Truskaw and Mościska, can only mean larger land-use density within the existing borders. Unfortunately, location of new service facilities in the main municipal village Izabelin $\mathrm{C}$ can not improve accessibility of the 1st level services in the units located in the Park or in the periphery of the municipality. In Sieraków village, which is located in the Park, one can not count neither on social, nor infrastructural development, because of current legal limitation considering settlement area located in national parks.

\section{Conclusions from the analysis of the social infrastructure development barriers due to environmental conditions}

Analysis of spatial and social data draw the following general conclusions considering sustainable social development of the Izabelin Municipality:

- natural areas are not spatial barriers in accessing 1st level service within the area of a particular settlement unit,

- natural areas become a barrier to the development of new service area,

- individual educational objects (primary and secondary schools) do not provide appropriate service to inhabitants of the Municipality (the eastern part of the Municipality is in the range of service facilities in Warsaw),

- if demographic forecast will come true in terms of quantity, number of 1 st level service facilities will be insufficient and it will cause need for new locations for services which will certainly interfere with natural values of the area,

- access to education, health and public security services in villages located in the Izabelin Municipality is very good in Izabelin C, good in Hornówek and Laski, medium in Izabelin B and Sieraków, low in Truskaw and Mościska,

- settlement area is being developed mainly along main roads which causes natural diversification of access to 1 st level service (especially unfavorable for inhabitants living in peripheries of the villages). At the same time, close location to forest area limits spatial development of the villages.

The final statement is that sustainable social development of the Izabelin Municipality will be strongly limited, both in terms of population growth and new building areas, through sustainable (ecological) environmental protection. Especially in the village Sieraków, which is situated within the National Park.

\section{References}

Bank danych regionalnych [Regional Data Bank], 19952008, GUS [Central Statistical Office], Warszawa.

Cembrzyńska-Niebudek E. \& Makarewicz R., 2004, Studium uwarunkowań i kierunków zagospodarowania przestrzennego Gminy Izabelin [The study of the conditions and directions of the spatial management of the Izabelin Municipality], Izabelin.

Chmielewski J. M., 2001, Teoria urbanistyki w projektowaniu i planowaniu miast [The theory of urban design and urban planning], Oficyna Wydawnicza Politechniki Warszawskiej, Warszawa.

COUNCIL DIRECTIVE 79/409/EEC of 2 April 1979 on the conservation of the wild birds.

COUNCIL DIRECTIVE 92/43/EEC of 21 May 1992 on the conservation of natural habitats and of wild fauna and flora.

Dz. U., 1991, Nr 95 poz. 425, Ustawa o systemie oświaty z dn. 7 września 1991 r. [The Education Act of 7 September 1991].

Kulikowski R., 2002, Problemy społeczne wsi i rolnictwa w Polsce [Social problems of rural areas and agriculture in Poland], [in:] J. Bański, E. Rydz (eds.) Społeczne problemy wsi,Studia obszarów wiejskich, t. 2 [Social problems of rural areas, Rural Studies, vol. 2], PAN, Instytut Geografii Zagospodarowania Przestrzennego, Warszawa: 9-17.

Liro A. (ed.), 1995, Koncepcja krajowej sieci ekologicznej ECONET-POLSKA [Concept of the National Ecological Network ECONET-POLAND], Fundacja IUCNPoland, Warszawa

Michalski T., 2002, Uwarunkowania sytuacji zdrowotnej ludności wiejskiej w Polsce [Preconditions of health status of rural population in Poland], [in:] J. Bański, E. Rydz (eds.) Społeczne problemy wsi, Studia obszarów wiejskich, t. 2 [Social problems of rural areas, Rural Studies, vol. 2], PAN, Instytut Geografii Zagospodarowania Przestrzennego, Warszawa: 31-39.

Podawca K., Makarewicz R. \& Olszewski S., 2005, Analiza zmian w zagospodarowaniu przestrzennym gminy Izabelin w latach 1996-2004 [Analysis of spatial management changes in the Izabelin Municipality in the years 1996-2004], Politechnika Warszawska, Wydział Architektury, Podyplomowe Studium Urbanistyki i Gospodarki Przestrzennej, Warszawa, typescript.

Rydz E., 2002, Bariery edukacyjne młodzieży wiejskiej [Educational barriers of rural youth], [in:] J. Bański, E. Rydz (eds.), Społeczne problemy wsi, Studia obszarów wiejskich, t. 2 [Social problems of rural areas, Rural Studies, vol. 2], PAN, Instytut Geografii Zagospodarowania Przestrzennego, Warszawa: 53-68. 
Sowa J., 2002, Rozwój Gminy Izabelin w obrębie wpływów Kampinoskiego Parku Narodowego [Development of the Izabelin Municicpality within the area of influence of the Kampinoski National Park], [in:] A. Stasiak (ed.) Kampinoski Park Narodowy wobec wyzwań antropopresji [ Kampinoski National Park towards the chalanges of antopopresion], Biuletyn KPZK PAN No. 202, Warszawa: 96-105.
Stola W., 1987, Klasyfikacja funkcjonalna obszarów wiejskich Polski [Functional classification of Polish rural areas], PAN, Instytut Geografii Zagospodarowania Przestrzennego, Ossolineum, Wrocław.

Wieczorkiewicz W., 1995, Planowanie przestrzenne osadnictwa wiejskiego [Spatial planning of rural settlement areas],Wydawnictwo SGGW, Warszawa.

www.izabelin.pl 